\title{
CS Research Suare \\ Chromosomal Characteristics and Prognostic Analysis of Secondary Acute Myeloid Leukemia
}

\section{Mingzhu Song}

Department of Hematology, The Second Affiliated Hospital of Anhui Medical University

\section{Tun Zhang}

Department of Hematology, The Second Affiliated Hospital of Anhui Medical University

\section{Dongdong Yang}

Second Affiliated Hospital of Anhui Medical University

\section{Hao Xiao}

Department of Hematology, The Second Affiliated Hospital of Anhui Medical University

\section{Huiping Wang}

Department of Hematology, The Second Affiliated Hospital of Anhui Medical University

\section{Zhimin Zhai}

Department of Hematology, The Second Affiliated Hospital of Anhui Medical University

Qianling Ye ( $\nabla$ yeqianling1@163.com)

Department of Hematology, The Second Affiliated Hospital of Anhui Medical University https://orcid.org/00000003-0013-7528

\section{Research Article}

Keywords: secondary acute myeloid leukemia, chromosome karyotype, survival, lactate dehydrogenase

Posted Date: February 15th, 2021

DOI: https://doi.org/10.21203/rs.3.rs-196191/v1

License: (a) (i) This work is licensed under a Creative Commons Attribution 4.0 International License. Read Full License 


\section{Abstract}

Background

Secondary Acute Myeloid Leukemia (S-AML) patients generally have a poor prognosis, and the chromosomal karyotype of S-AML have been rarely reported in the published literature. We aimed to explore the chromosomal karyotype and its clinical significance in patients with S-AML.

\section{Methods}

Clinical characteristics and chromosome karyotypes of 26 patients with S-AML were retrospectively analyzed. The overall survival (OS) was measured from the time of the patients' transition to AML (which means the time of SAML diagnosis) .

Results

Among the 26 S-AML patients, there were 13 males and 13 females, with a median age of 63 years old (range, 2077 years old). All of them were secondary to a variety of hematologic malignancies or solid tumors, and most of them were secondary to myelodysplastic syndrome (MDS). About $62 \%$ of the S-AML patients showed chromosome abnormalities. The level of serum lactate dehydrogenase (LDH) in S-AML patients with abnormal chromosome karyotype was higher than those with normal chromosome karyotype. Apart from the differences in treatment regimens, S-AML patients with chromosomal karyotype abnormalities had shorter OS $(P<0.05)$.

Conclusions

S-AML patients with abnormal chromosomal karyotype have higher LDH and shorter OS than normal chromosomal karyotype, and the OS of hypodiploidy was much shorter than hyperdiploid.

\section{Introduction}

Secondary acute myeloid leukemia (S-AML) refers to AML developing either after a prior hematologic disorder, usually myelodysplastic syndrome (MDS), or after exposure to cytotoxic drugs or chemotherapy[1, 2]. Compared with newly diagnosed primary AML (P-AML), S-AML has a poorer prognosis, lower remission rates, and shorter OS $[3,4]$. Although the use of intensive chemotherapy regimens, the prognosis of S-AML patients is still poor, especially in elderly patients[1].

Recent advances in genomic analysis have revealed a large number of chromosomal abnormalities associated with AML onset and recurrence[5]. The recognition and understanding of chromosomal abnormalities for the diagnosis and treatment of AML patients is of great significance[6]. Chromosomal abnormalities are likely to be associated with disease progression in S-AML[7].

Some major clinical features, such as WBC and LDH were significant additive features for OS[8]. A high level of LDH is a poor prognostic factor for AML, and LDH was initially identified as an influence factor for OS[9]. We analyzed the clinical characteristics and chromosomal abnormalities of $26 \mathrm{~S}$-AML patients to further explore the possible pathogenesis of S-AML patients.

\section{Patients And Methods}




\section{Patients}

A total of 26 S-AML patients who were diagnosed or treated in the Second Affiliated Hospital of Anhui Medical University from January 2009 to January 2020 were collected. All the newly diagnosed S-AML patients met the 2008 or 2016 WHO criteria[10,11]. Clinical characteristics of all the patients were obtained from medical records. The study was performed in accordance with the principles expressed in the Declaration of Helsinki. Chromosome karyotype analysis

Of the 26 S-AML patients, 25 had a cytogenetic analysis performed at the time of the patients' transition to AML (which means at the time of S-AML diagnosis). All cytogenetic investigations were carried out in a standardized fashion at the Chromosome Laboratory, Department of Hematology. The analysis specimens were prepared by the bone marrow short-term culture method, and the Gimsa banding method was used. Chromosome analysis of 20 metaphase spreads were examined per patient, if available, and the International System for Human Cytogenetic Nomenclature (ISCN) was used to describe karyotypes[12].

\section{Laboratory examination}

According to the results of chromosome karyotype in S-AML patients, the patients were divided into normal group (both number and structure are normal) and abnormal group (number or structure abnormalities), and the differences of some laboratory examination between the two groups were compared. Laboratory examination were obtained from medical records, including red blood cell (RBC) counts, white blood cell (WBC) counts, platelet counts (PLT), lymphocyte counts (LYM), mononuclear cell counts (MO), neutrophil counts (NEUT), hemoglobin $(\mathrm{Hb})$, hypersensitive c-reactive protein (Hs-CRP) and lactate dehydrogenase (LDH), using the fully automated hematology analyzer Sysmex XE-2100 (Sysmex Corporation, Japan) and the fully automated biochemical analyzer AU5831 (Beckman Coulter, America).

\section{Follow up}

Patients were followed to the earliest of death, loss to follow-up or the end of the follow-up time on July $20,2020$. OS was calculated from the time of S-AML diagnosis to the date of death or last follow-up. Medical record retrieval and telephone follow-up were performed during the study.

\section{Statistical analysis}

Student's t-test was used to test the differences between the two groups for quantitative normally distributed variables and the Mann-Whitney $U$ test was used for non-parametric variables. Kaplan-Meier survival curves were used for estimating OS. Statistical analyses were performed with the IBM SPSS 25.0. Results were considered significant at $p<0.05$.

\section{Results}

\section{Patient characteristics}

26 S-AML patients were enrolled in the study, and the median age was 63 years (range, 20-77 years). Of these, half of the patients were men. Most of them were secondary to MDS (one of them was secondary to MDS, but coexisted with chronic lymphocytic anemia (CLL)), the rest of the patients were secondary to myelodysplastic-

myeloproliferative neoplasms (MDS/MPN), chronic myeloid leukemia (CML), chronic myelomonocytic leukemia 
(CMML), primary myelofibrosis (PMF), gastric diffuse large B cell lymphoma and rectal cancer. Other clinical features were also collected, such as treatment, which is an important determinant of OS, as well as factors that are closely related to patient prognosis.

It is of great significance to choose the appropriate chemotherapy regimen for the efficacy of patients with AML. In clinical practice, individualized treatment regimen is often made according to the patient's tolerance and other specific conditions. In our study, many patients were treated with decitabine in combination with other regiments. Desitabine is a demethylation agent that is effective and safe in older patients with $A M L$, and its combination with another regimen (CAG/HAG, retinoic acid) results in a higher OR rate than desitabine alone[13]. However, other optional regiments such as azacytidine, IA/IAG regimen, and intrathecal injection have also been used in the treatment of patients, depending on the patient's condition. The basic characteristics of $26 \mathrm{~S}-\mathrm{AML}$ patients was shown in Table 1. 
Table 1

The basic characteristics of 26 S-AML patients

\begin{tabular}{|c|c|c|c|c|c|c|c|}
\hline No & Gender & Age & $\begin{array}{l}\text { Original } \\
\text { diagnosis }\end{array}$ & AML & $\begin{array}{l}\text { Treatment(after the time } \\
\text { of S-AML diagnosis) }\end{array}$ & $\begin{array}{l}\text { Outcome } \\
\text { (until } \\
\text { July 20, } \\
\text { 2020) }\end{array}$ & $\begin{array}{l}\text { OS } \\
\text { (Days) }\end{array}$ \\
\hline 1 & Male & 72 & MDS & M7 & Decitabine alone & death & 80 \\
\hline 2 & Female & 56 & MDS & M2 & $\begin{array}{l}\text { Decitabine + CAG(Ara-C, } \\
\text { Aclarubicin, and G-CSF), } \\
\text { HAAG(Homoharringtonine, } \\
\text { Ara-C, Aclarubicin, and G- } \\
\text { CSF) }\end{array}$ & death & 211 \\
\hline 3 & Male & 76 & MDS & M2 & $\begin{array}{l}\text { Decitabine + CAG(Ara-C, } \\
\text { Aclarubicin, and G-CSF ) + } \\
\text { ATO }\end{array}$ & death & 575 \\
\hline 4 & Female & 65 & MDS & M4 & $\begin{array}{l}\text { No, and we don't know if } \\
\text { the patient was treated at } \\
\text { any other hospital }\end{array}$ & survival & 600 \\
\hline 5 & Female & 66 & MDS & AML(unclassified) & $\begin{array}{l}\text { No, and we don't know if } \\
\text { the patient was treated at } \\
\text { any other hospital }\end{array}$ & death & 485 \\
\hline 6 & Female & 62 & MDS & AML(unclassified) & $\begin{array}{l}\text { CAG(low dose Cytarabine, } \\
\text { Aclarubicin, and G-CSF ) + } \\
\text { ATO + EPO }\end{array}$ & death & 55 \\
\hline \multirow[t]{4}{*}{7} & Female & 65 & MDS & M2 & $\begin{array}{l}\text { IAG(idarubicin + Ara-C + G- } \\
\text { CSF), DAIDaunorubicin + } \\
\text { Ara-C) }\end{array}$ & death & 108 \\
\hline & & & & & $\begin{array}{l}\text { Azacitidine }+ \\
\text { HAG(Homoharringtonine, } \\
\text { Ara-C, and G-CSF) }\end{array}$ & & \\
\hline & & & & & $\begin{array}{l}\text { intrathecal injection(MTX, } \\
\text { DXM, and Ara-C) }\end{array}$ & & \\
\hline & & & & & $\begin{array}{l}\text { Decitabine, thalidomide, } \\
\text { ubenimex, Lenalidomide, } \\
\text { Tretinoin, TPO }\end{array}$ & & \\
\hline 8 & Male & 61 & MDS & AML(unclassified) & $\begin{array}{l}\text { Decitabine + CAG(Ara-C, } \\
\text { Aclarubicin, and G-CSF) }\end{array}$ & $\begin{array}{l}\text { loss to } \\
\text { follow- } \\
\text { up }\end{array}$ & 10 \\
\hline
\end{tabular}




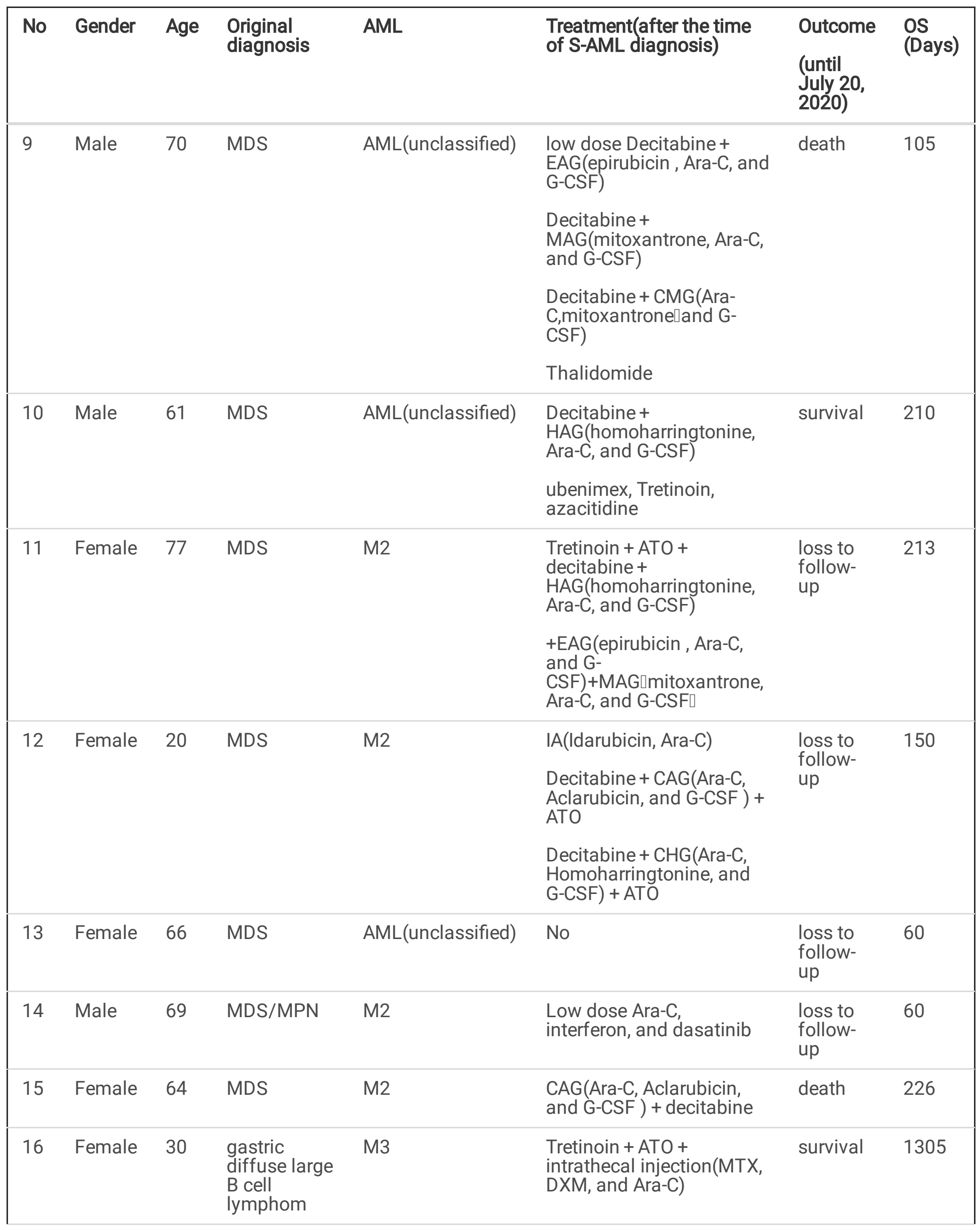




\begin{tabular}{|c|c|c|c|c|c|c|c|}
\hline No & Gender & Age & $\begin{array}{l}\text { Original } \\
\text { diagnosis }\end{array}$ & AML & $\begin{array}{l}\text { Treatment(after the time } \\
\text { of S-AML diagnosis) }\end{array}$ & $\begin{array}{l}\text { Outcome } \\
\text { (until } \\
\text { July 20, } \\
\text { 2020) }\end{array}$ & $\begin{array}{l}\text { OS } \\
\text { (Days) }\end{array}$ \\
\hline \multirow[t]{3}{*}{17} & Male & 46 & $\mathrm{CML}$ & AML(unclassified) & $\begin{array}{l}\text { DA(Daunorubicin + Ara- } \\
\text { C)Idarubicin }\end{array}$ & death & 180 \\
\hline & & & & & $\begin{array}{l}\text { HAG(Homoharringtonine, } \\
\text { Ara-C, and G-CSF) }\end{array}$ & & \\
\hline & & & & & $\begin{array}{l}\text { Dasatinib + Imatinib(Oral } \\
\text { administration of } \\
\text { dasatinib and imatinib } \\
\text { was subsequently } \\
\text { discontinued because of } \\
\text { the T325I mutation, which } \\
\text { suggested resistance to } \\
\text { all tyrosine kinases), } \\
\text { Hydroxycarbamide, } \\
\text { etoposide, and ATO. }\end{array}$ & & \\
\hline \multirow[t]{6}{*}{18} & Male & 61 & CMML & M2 & IA(Idarubicin, Ara-C) & death & 323 \\
\hline & & & & & $\begin{array}{l}\text { Decitabine + CAG(Ara-C, } \\
\text { Aclarubicin, and G-CSF ) }\end{array}$ & & \\
\hline & & & & & $\begin{array}{l}\text { Decitabine + } \\
\text { HAG(homoharringtonine, } \\
\text { Ara-C, and G- } \\
\text { CSF)+Tretinoin + ATO }\end{array}$ & & \\
\hline & & & & & $\begin{array}{l}\text { Stanozolol, etoposide, } \\
\text { ubenimex, and } \\
\text { thalidomide }\end{array}$ & & \\
\hline & & & & & $\begin{array}{l}\text { Dorubicin liposomes and } \\
\text { hexadecadrol }\end{array}$ & & \\
\hline & & & & & $\begin{array}{l}\text { Low dose methotrexate, } \\
\text { and azacitidine }\end{array}$ & & \\
\hline \multirow[t]{3}{*}{19} & Female & 55 & PMF & M2 & $\begin{array}{l}\text { Decitabine + IA(Idarubicin, } \\
\text { Ara-C) }\end{array}$ & death & 143 \\
\hline & & & & & $\begin{array}{l}\text { Hematopoietic stem cell } \\
\text { microtransplantation }\end{array}$ & & \\
\hline & & & & & $\begin{array}{l}\text { DAE (Doxorubicin + Ara-C } \\
\text { + Etoposide) }\end{array}$ & & \\
\hline 20 & Male & 61 & $\begin{array}{l}\text { MDS(coexist } \\
\text { with CLL) }\end{array}$ & AML(unclassified) & $\begin{array}{l}\text { ATO + VP-16 + Ara-C + G- } \\
\text { CSF }\end{array}$ & death & 62 \\
\hline
\end{tabular}




\begin{tabular}{|c|c|c|c|c|c|c|c|}
\hline No & Gender & Age & $\begin{array}{l}\text { Original } \\
\text { diagnosis }\end{array}$ & AML & $\begin{array}{l}\text { Treatment(after the time } \\
\text { of S-AML diagnosis) }\end{array}$ & $\begin{array}{l}\text { Outcome } \\
\text { (until } \\
\text { July 20, } \\
\text { 2020) }\end{array}$ & $\begin{array}{l}\text { OS } \\
\text { (Days) }\end{array}$ \\
\hline \multirow[t]{3}{*}{21} & Female & 66 & CMML & M4 & $\begin{array}{l}\text { Decitabine + } \\
\text { HAG(homoharringtonine, } \\
\text { Ara-C, and G-CSF) }\end{array}$ & $\begin{array}{l}\text { loss to } \\
\text { follow- } \\
\text { up }\end{array}$ & 328 \\
\hline & & & & & $\begin{array}{l}\text { Low dose Decitabine + } \\
\text { ATO + DAG(Daunorubicin } \\
+ \text { Ara-C + G-CSF) }\end{array}$ & & \\
\hline & & & & & $\begin{array}{l}\text { Etoposide, Ara-C, and } \\
\text { azacitidine }\end{array}$ & & \\
\hline 22 & Male & 38 & PMF & M5 & $\begin{array}{l}\text { ME ( Mitoxantrone, } \\
\text { Etoposide), } \\
\text { homoharringtonine, Ara-C, } \\
\text { ATO }\end{array}$ & $\begin{array}{l}\text { loss to } \\
\text { follow- } \\
\text { up }\end{array}$ & 450 \\
\hline \multirow[t]{4}{*}{23} & Male & 72 & rectal cancer & M2 & $\begin{array}{l}\text { Decitabine + CAG(Ara-C, } \\
\text { Aclarubicin, and G-CSF) }\end{array}$ & survival & 2560 \\
\hline & & & & & CTK cell infusion & & \\
\hline & & & & & G- CSF, Ara-C, ATO & & \\
\hline & & & & & $\begin{array}{l}\text { Decitabine }+ \text { darubicin or } \\
\text { Pirarubicin }+ \text { Ara-C }\end{array}$ & & \\
\hline 24 & Female & 67 & rectal cancer & AML(unclassified) & Decitabine + Ara-C & death & 21 \\
\hline \multirow[t]{4}{*}{25} & Male & 32 & CML & AML(unclassified) & $\begin{array}{l}\text { MA(Mitoxantrone, and } \\
\text { Ara-C) }\end{array}$ & death & 270 \\
\hline & & & & & $\begin{array}{l}\text { CAG(Ara-C, Aclarubicin, } \\
\text { and G-CSF ) }\end{array}$ & & \\
\hline & & & & & Dasatinib, methotrexate & & \\
\hline & & & & & $\begin{array}{l}\text { intrathecal injection(MTX, } \\
\text { DXM, and Ara-C) }\end{array}$ & & \\
\hline 26 & Male & 44 & $\mathrm{CML}$ & M2 & No & $\begin{array}{l}\text { loss to } \\
\text { follow- } \\
\text { up }\end{array}$ & 5 \\
\hline
\end{tabular}

\section{Chromosome Karyotype Test Results}

More than half of the S-AML patients had chromosomal abnormalities $(16 / 26)$, and the majority of patients $(10 / 16)$ with abnormal chromosome karyotypes had detected abnormalities on chromosome 5 or 7 . Chromosome abnormality showed numerical abnormalities and structural abnormalities which involved in most chromosomes. Hypodiploidy and hyperdiploidy were two more classifications of AML. In our study, hypodiploid karyotype was found in 5 patients and hyperdiploid karyotype in 7 patients. The abnormalities include: addition (add), insertion (ins), deletion (del), marker chromosome (mar), incomplete karyotype (inc), derived chromosome (der), inversion (inv), isochromosome (i), ring chromosome (r), etc. Karyotypes from the 26 patients with clonal aberrations were listed in Table 2. 
Table 2

Chromosome karyotypes of the 26 S-AML patients

\begin{tabular}{|c|c|c|}
\hline \multicolumn{2}{|c|}{ Karyotypes (N) } & \multirow{3}{*}{$\begin{array}{l}\text { Chromosome of S-AML } \\
46, X Y\end{array}$} \\
\hline Normal & Diploid & \\
\hline (10) & (10) & \\
\hline \multirow{16}{*}{$\begin{array}{l}\text { Abnormal } \\
(16)\end{array}$} & \multirow{5}{*}{$\begin{array}{l}\text { Diploid *\# } \\
\text { (7) }\end{array}$} & $46, \mathrm{XY},-7,+$ marker. $[10]$ \\
\hline & & $46, X X[3] / 46, X X,+\operatorname{der}(8) \operatorname{del}(q 22), \operatorname{del}(12)(p 11),-2,-5,-7,-11,-17,+22,+$ marker*3[17] \\
\hline & & $46, X Y, \operatorname{del}(5) q(23), \operatorname{add}(17) p(12),-9,12,20$, marker $\times 3 .[5]$ \\
\hline & & $46, X Y, t(9 ; 22)(q 34 ; q 11), t(2 ; 12 ; 15),(p 13 ; q 13 ; p 11),+8 .[20]$ \\
\hline & & é $46, X Y, t(9 ; 22)(q 34 ; q 11)[8] / 46, X Y, t(9 ; 22)(q 34 ; q 11), \operatorname{ins}(3 ; 3)(q 25 ; q 21 q 25)[5]$ \\
\hline & \multirow{5}{*}{$\begin{array}{l}\text { hypodiploid* } \\
\text { (5) }\end{array}$} & $45, X Y, \operatorname{add}(3)(q 29), \operatorname{del}(5)(q 23), \operatorname{add}(12)(p 15),-7 .[20]$ \\
\hline & & $\begin{array}{l}\text { \# 43-46,XX.-2,-3,?add(3)(q11), del(5)(q13q31), del(7)(q31), add(11) } \\
\text { (p15),-15,-17,add(17)(p13),-18,add(19)(p13),add(22)(q13) + mar,inc[cp20]. }\end{array}$ \\
\hline & & $\begin{array}{l}43, X, t(5 ; 19)(q 21 ; q 13), 7 q+,-7,-12,-20,-Y,+ \text { marker. } \\
{[7] / 44, X Y, 5 q-, 7 q+,-12,-18,-20,+ \text { marker1,+marker2.[13] }}\end{array}$ \\
\hline & & $\begin{array}{l}\text { 45,XY,-5,-9,+mar[7]/45,XY,del(5)(q15),-9,add(11)(q25)[4]/44,XY,add(5)(p15), del(5) } \\
\text { (q15),del(7)(q11),der(12)del(12)(p12)add(12)(p12),-13,-19,-21,+mar[5] }\end{array}$ \\
\hline & & $\begin{array}{l}\text { * } 40-48 \text { XX,add(1)(p36),add(2)(q37),del(5)(q15), add(12) } \\
(\text { p13),-8,-9,-11,-22,+marker×3.inc.[cp15] }\end{array}$ \\
\hline & \multirow{6}{*}{$\begin{array}{l}\text { hyperdiploid* } \\
\text { (7) }\end{array}$} & $47, \mathrm{XX},+8 .[20]$ \\
\hline & & 48,XXX,del(20)(q13),+X,+marker.[8]/48,XX,del(20)(q13),+14,+marker.[3] \\
\hline & & $48, X Y, \operatorname{inv}(3)(q 21 q 26),+8, t(9 ; 22)(q 34 ; q 11), i(17)(q 11),+\operatorname{der}(22) t(9 ; 22)(q 34 ; q 11)[20]$ \\
\hline & & $48, X Y, 20 q-,+8,+13 .[5]$ \\
\hline & & $\begin{array}{l}48, \mathrm{XX}, \mathrm{t}(1 ; ?)(\mathrm{q} 21 ; ?),+\operatorname{der}(1) \mathrm{t}(1 ; ?)(\mathrm{p} 32 ; ?),-6,-7,+14,+19,+\mathrm{r}[\mathrm{8}] / 48, \mathrm{XX}, \mathrm{t}(1 ; ?) \\
(\mathrm{q} 21 ; ?),+\operatorname{der}(1) \mathrm{t}(1 ; ?)(\mathrm{p} 32 ; ?),-6,-7,+14,+19,+ \text { marker.[2] }\end{array}$ \\
\hline & & $47, X Y, 5 q-,+8 .[15]$ \\
\hline
\end{tabular}

éthe chromosome of the patient was collected at primary diagnosis (2 months ago); ${ }^{*}$ the chromosome contains in all the three kinds of abnormal karyotypes of chromosome ; ${ }^{*}$ the chromosome contains in both diploid and hypodiploid of abnormal karyotypes of chromosome.

\section{Chromosome Karyotypes And Laboratory Examination}

The S-AML patients were divided into two groups according to whether the chromosomal karyotype was normal or not, and Mann-Whitney $U$ test was used for comparison between the two groups. The results showed that there was a statistical difference in LDH level between the two groups, and LDH level was higher in S-AML patients with chromosomal abnormalities $(P<0.05)$. The scatter diagram was drawn show the level of LDH between normal and abnormal chromosome karyotypes (Fig. 1). RBC, WBC, PLT and other laboratory examination showed no significant difference between normal and abnormal karyotypes (Table 3). 
Table 3

Laboratory examination in normal and abnormal chromosome karyotypes

\begin{tabular}{|llll|}
\hline laboratory examination & $\begin{array}{l}\text { Normal } \\
\text { chromosome karyotypes } \\
(\mathbf{n}=10) \\
\text { median (range) }\end{array}$ & $\begin{array}{l}\text { Abnormal } \\
\text { chromosome karyotypes } \\
(\mathbf{n}=16)\end{array}$ & $P$ \\
median (range) & \\
\hline $\mathrm{RBC}\left(\times 10^{\wedge} 12 / \mathrm{L}\right)$ & $2.16(1.47-3.94)$ & $1.98(1.38-5.49)$ & 0.551 \\
\hline $\mathrm{WBC}\left(\times 10^{\wedge} 9 / \mathrm{L}\right)$ & $1.96(0.3-11.13)$ & $3.28(0.33-47.17)$ & 0.391 \\
\hline $\mathrm{PLT}\left(\times 10^{\wedge} 9 / \mathrm{L}\right)$ & $13.5(3-269)$ & $28.5(5-207)$ & 0.262 \\
\hline $\mathrm{LYM}\left(\times 10^{\wedge} 9 / \mathrm{L}\right)$ & $1.09(0.27-2.82)$ & $0.82(0.14-22.08)$ & 0.816 \\
\hline $\mathrm{MO}\left(\times 10^{\wedge} 9 / \mathrm{L}\right)$ & $0.14(0-2.09)$ & $0.41(0-15.89)$ & 0.165 \\
\hline $\mathrm{NEUT}\left(\times 10^{\wedge} 9 / \mathrm{L}\right)$ & $0.34(0-9.35)$ & $1.72(0.02-36.62)$ & 0.182 \\
\hline $\mathrm{Hb}(\mathrm{g} / \mathrm{L})$ & $66.5(44-121)$ & $64(49-152)$ & 0.363 \\
\hline $\mathrm{hsCRP}(\mathrm{mg} / \mathrm{L})$ & $61(0.3-87.2)^{\mathrm{a}}$ & $39(1.5-193.7)$ & 0.452 \\
\hline $\mathrm{LDH}(\mathrm{U} / \mathrm{L})$ & $163.5(65-220)^{\mathrm{b}}$ & $274(71-1406)^{\mathrm{c}}$ & 0.008 \\
\hline $\mathrm{a} \mathrm{n}=9 ;{ }^{\mathrm{b}} \mathrm{n}=8 ;{ }^{\mathrm{c}} \mathrm{n}=15$ & & & \\
\hline
\end{tabular}

\section{Overall Survival (os)}

The median OS of normal chromosome karyotypes was 212 days, while that for patients with abnormal chromosome karyotypes was 162 days. The outcome of S-AML patients with normal chromosomal karyotype was: 2 died, 3 survived, and 5 were lost to follow-up. The outcome of S-AML patients with abnormal chromosomal karyotype was: 12 were died, 1 was survived, and 3 were lost to follow-up. What's more, All five patients with hypodiploidy karyotype died, with a median survival of 62 days. Of the 7 patients with hyperdiploid karyotype, 5 were died, 1 was still alive, and 1 was lost to follow-up, with median survival time of 211 days. The results of the Kaplan-Meier survival curve showed that the OS of S-AML patients with abnormal chromosome karyotypes was shorter than that of S-AML patients with normal chromosome karyotypes $(P=0.038)$ (Fig. 2). Kaplan-meier survival curve showed that compared with normal chromosomes, the OS of hyperdiploid was shorter, while the OS of hypodiploidy was much shorter $(P=0.038)$ (Fig. 3).

\section{Discussion}

S-AML is a heterogeneous disease that increases in frequency with age, remains a challenge to therapy[14]. Myelodysplastic syndrome (MDS) is characterized by cytopenia, osteomyelodysplasia, hematopoietic dysfunction, and a high risk of transition to AML[15]. More than half of the S-AML patients reported in this study converted from MDS to AML. Compared with primary AML patients, S-AML patients have worse clinical prognosis, including complete remission rate (CR), recurrence free survival rate and OS rate[16]. Our previous study showed that abnormal increase of peripheral blood regular T cells (Treg) cells may cause the imbalance of immune status of SAML patients, which may be relevant to poor chemotherapy effect and short survival time of S-AML patients[17]. It 
has been reported in the literature that there are tumor suppressor genes on chromosome 6q, 7p, 10p, 11q, 14q and $20 q$, which play an important role in the transformation from MDS to AML[18]. Chromosomes are associated with the progression of S-AML patients, and deserved further study. The purpose of this study was to analyze the chromosome karyotype results of S-AML patients and further explore the factors connected with survival and prognosis of S-AML patients in combination with relevant laboratory examinations.

Our results indicated that most S-AML patients had abnormal chromosome karyotype, including autosomal and sex chromosomal abnormalities. Abnormal changes of autosomal karyotypes were more common in S-AML patients and were closely related to survival prognosis. Studies have shown a more incidence of abnormalities on chromosomes 5 and 7 in patients with S-AML[19, 20]. In our study, 62.5\% (10/16) abnormal chromosome karyotypes had abnormalities on chromosomes 5 and 7. Admittedly, our data are limited and we do not have much information based on the results of only 26 S-AML patients. Abnormal changes of sex chromosomes have been rarely reported in myeloid malignancies[21]. We found an extra sex chromosome (X chromosome) in a FAB-M4 patient who was transformed from MDS in an elderly woman, and the abnormal chromosome karyotypes were: 48,XXX,del(20)(q13),+X,+marker.[8]/48,XX,del(20)(q13),+14,+marker.[3]. The patient was still alive. We also detected $Y$ chromosome deletion in an elderly male patient with AML transformed by MDS, and the abnormal karyotype was: 43,X,t(5;19)(q21;q13),7q+,-7,-12,-20,-Y,+marker.[7]/44,XY,5q-,7q+,-12,-18,-20,+marker1,+marker2.[13]. Unfortunately, the patient lost to follow-up, and we couldn't know whether the patient lives or dies. Some studies have suggested that $Y$ chromosome loss is an age-related phenomenon with no prognostic significance[22]. Studies have shown that sex chromosome loss increases with age, and that $Y$ chromosome loss reduces the risk of converting MDS patients to leukemia[23]. Loss of X chromosome may be associated with a better prognosis in female AML patients with $t(8 ; 21)$, and loss of $Y$ chromosome may be associated with a high level of recurrence rate in men AML patients with $\mathrm{t}$ (8:21)[24]. The relationship between sex chromosome abnormality and survival in S-AML patients needs to be further explored by expanding the data.

LDH not only plays an important role in the early diagnosis and prognosis of many solid tumors, but also plays an important part in evaluating the severity of leukemia patients[25, 26]. LDH is positively correlated with tumor burden and is an independent prognostic factor for early death in hyperleukocytic AML[27]. Compared with the normal karyotype group, our results showed that LDH levels were significantly increased in the abnormal karyotype group. It suggested that the higher LDH level in S-AML patients, the greater the tumor burden, the greater the possibility of chromosomal karyotype abnormality, and the worse the OS rate. To conclude, abnormalities of LDH and chromosomal karyotypes are closely related to the severity and survival prognosis of S-AML patients, which may be a very valuable indicator for further risk stratification of S-AML in the future.

Most AML patients with chromosome number abnormalities may be manifested by an increase of 1-2 chromosomes (47-48 chromosomes), known as low hyperdiploid, and rare high hyperdiploidy (49-65 chromosomes), both of which are associated with poor outcome in AML[28-30]. It has also been reported that there was no difference in 5-yaar OS and EFS between AML patients with non-hyperdiploid and hyperdiploid karyotypes (48-65 chromosomes)[31]. Hypodiploidy (<46 chromosomes) has been reported mostly in acute lymphoblastic leukemia (ALL), but rarely in AML[32-34]. However, there is currently lack of further research on the prognosis of survival in S-AML patients with hyperdiploid or hypodiploid. In addition to other factors affecting OS, such as various treatment regimens, our research found that chromosome karyotype were closely relevant to the survival of S-AML patients, and patients with abnormal chromosomal karyotypes demonstrated inferior OS compared with those normal chromosomal. What's more, S-AML patients with hypodiploid showed worse outcome than those with hyperdiploid. 
There are some limitations in our study. Firstly, the abnormality of sex chromosomes may be related to the survival prognosis of S-AML, but no definite conclusion could be drawn because of the small number of sex chromosome abnormalities in our study. Apart from this, the accurate information of all patients could not be obtained through telephone follow-up in this study, which may interfere with the experimental results. Additionaly, this study is a single-center retrospective study, and the number of included cases is relatively small, so it needs to further expand the sample size for study. Moreover, with the heterogeneity of the individualized treatment among AML patients, treatment regimens would constitute an important source of limitation, which may have exerted some influence on the results.

In conclusion, our reaearch highlights the contribution of chromosomes, as well as LDH, leading to poor prognosis of S-AML, and the abnormity of sex chromosomes may be associated with the survival prognosis of S-AML patients. Understanding the multifactorial contributions will lead to more precise risk classification and treatment strategies. More factors related to the survival and prognosis of S-AML need to be explored, which may contribute to monitoring the progression of the disease, early diagnosis and treatment.

\section{Declarations}

\section{Authors' contributions}

Qianling Ye and Zhimin Zhai designed the study. Tun Zhang, Huiping Wang and Hao Xiao collected patients' data. Dongdong Yang was responsible for chromosome analysis. Mingzhu Song prepared the figures and drafted the manuscript. All authors read and approved the final manuscript.

\section{Funding}

This article was funded by the National Natural Science Foundation of China, grant number 81602914.

\section{Data availability}

The datasets used and/or analyzed during the current study are available from the corresponding author on reasonable request.

\section{Compliance with ethical standards}

Conflicts of interest The authors declare no potential conflict of interest.

Ethic approval and consent to participate The study was performed in accordance with the principles expressed in the Declaration of Helsinki. Written informed consent was not required due to retrospective fashion of this study.

\section{References}

1. Ossenkoppele G, Montesinos P. Challenges in the diagnosis and treatment of secondary acute myeloid leukemia. Crit Rev Oncol Hematol. 2019; 138: 6-13. https://doi.org/10.1016/j.critrevonc.2019.03.003.

2. Leone G, Mele L, Pulsoni A, Equitani F, Pagano L. The incidence of secondary leukemias. Haematologica. 1999; 84(10): 937-45. http://www.ncbi.nlm.nih.gov/entrez/query.fcgi?

cmd=Retrieve\&db=pubmed\&dopt=Abstract\&list_uids=1050 9043\&query_hl=1. 
3. Hulegardh E, Nilsson C, Lazarevic V, et al. Characterization and prognostic features of secondary acute myeloid leukemia in a population-based setting: A report from the Swedish Acute Leukemia Registry. Am J Hematol. 2015; 90(3): 208-14. https://doi.org/10.1002/ajh.23908.

4. Granfeldt OL, Medeiros BC, Sengelov H, et al. Epidemiology and clinical significance of secondary and Therapy-Related acute myeloid leukemia: A national Population-Based cohort study. J Clin Oncol. 2015; 33(31): 3641-9. https://doi.org/10.1200/JC0.2014.60.0890.

5. Yamaguchi H. [Importance of gene mutation analysis as prognostic factor of acute myeloid leukemia]. Rinsho Ketsueki. 2020; 61(9): 1160 5.https://doi.org/10.11406/rinketsu.61.1160.

6. Liu M, Ren Y, Wang X, Lu X, Li M, Kim YMet al. Two rare cases of acute myeloid leukemia with $\mathrm{t}(8 ; 16)$ (p11.2;p13.3) and 1q duplication: Case presentation and literature review. Mol Cytogenet. 2020; $13: 37$. https://doi.org/10.1186/s13039-020-00507-0.

7. Ayres-Silva JP, Bonamino MH, Gouveia ME, et al. Genetic alterations in essential thrombocythemia progression to acute myeloid leukemia: A case series and review of the literature. Front Oncol. 2018; 8: 32. https://doi.org/10.3389/fonc.2018.00032.

8. Wan W, Wang J, Dong F, et al. [clinical characteristics and prognosis of 84 elderly patients with acute myeloid leukemia]. Zhongguo Shi Yan Xue Ye Xue Za Zhi. 2019; 27(3): 692-701. doi: 10.19746/j.cnki.issn.10092137.2019.03.009. PMID:31204918

9. Zhou F, Zhou F, Du M, et al. Comprehensive prognostic scoring systems could improve the prognosis of adult acute myeloid leukemia patients. Int J Hematol. 2019; 110(5): 575-83. https://doi.org/10.1007/s12185-01902721-y.

10. Vardiman JW, Thiele J, Arber DA, et al. The 2008 revision of the World Health Organization (WHO) classification of myeloid neoplasms and acute leukemia: Rationale and important changes. Blood. 2009; 114(5): 937-51. https://doi.org/10.1182/blood-2009-03-209262.

11. Arber DA, Orazi A, Hasserjian R, et al. The 2016 revision to the World Health Organization classification of myeloid neoplasms and acute leukemia. Blood. 2016; 127(20): 2391-405. https://doi.org/10.1182/blood-201603-643544.

12. Simons A, Shaffer LG, Hastings RJ. Cytogenetic Nomenclature: Changes in the ISCN 2013 Compared to the 2009 Edition. Cytogenet Genome Res. 2013; 141(1): 1-6. https://doi.org/10.1159/000353118.

13. Bian MR, Yang HS, Lin GQ, et al. Decitabine compared with conventional regimens in older patients with acute myeloid leukemia: A Meta-Analysis. Clin Lymphoma Myeloma Leuk. 2019; 19(12): e636-48. https://doi.org/10.1016/j.clml.2019.06.004

14. Collinge E, Loron S, Larcher MV, et al. Elderly Patients (Age 70 Years or Older) with Secondary Acute Myeloid Leukemia or Acute Myeloid Leukemia Developed Concurrently to Another Malignant Disease. Clin Lymphoma Myeloma Leuk. 2018; 18(5): e211-8. https://doi.org/10.1016/j.clml.2018.02.018.

15. Menssen AJ, Walter MJ. Genetics of progression from MDS to secondary leukemia. Blood. 2020; 136(1): 5060. https://doi.org/10.1182/blood.2019000942.

16. Cheung E, Perissinotti AJ, Bixby DL, Burke PW, Pettit KM, Benitez LLet al. The leukemia strikes back: A review of pathogenesis and treatment of secondary AML. Ann Hematol. 2019; 98(3): 541-59. https://doi.org/10.1007/s00277-019-03606-0. 
17. Qianling Y, Mingzhu S, Huiping W, Hao X, Zhimin Z. Detection of T cell subsets with secondary leukemia. Journal of Anhui Medical University. 2020; (09): 1469-71. (in Chinese).

18. Mori N, Morosetti R, Hoflehner E, Lubbert M, Mizoguchi H, Koeffler HP. Allelic loss in the progression of myelodysplastic syndrome. Cancer Res. 2000; 60(11): 3039-42. https://cancerres.aacrjournals.org/content/60/11/3039. PMID:10850454

19. Mannan A, Muhsen IN, Barragan E, et al. Genotypic and phenotypic characteristics of acute promyelocytic leukemia translocation variants. Hematol Oncol Stem Cell Ther. 2020; 13(4): 189-201. https://doi.org/10.1016/j.hemonc.2020.05.007.

20. Seymour JF, Juneja SK, Campbell LJ, Ellims PH, Estey EH, Prince HM. Secondary acute myeloid leukemia with inv(16): Report of two cases following paclitaxel-containing chemotherapy and review of the role of intensified ara-C therapy. Leukemia. 1999; 13(11): 1735-40. https://doi.org/10.1038/sj.leu.2401552.

21. Gurnari $C$, Panetta P, Fabiani E, et al. Identification of $i(X)(p 10)$ as the sole molecular abnormality in atypical chronic myeloid leukemia evolved into acute myeloid leukemia. Mol Clin Oncol. 2018; 8(3): 463-5. https://doi.org/10.3892/mco.2017.1543.

22. Zeidan A, Phatak P. Acquired biclonal chromosome $X$ aberrations without autosomal chromosomal anomalies in acute myeloid leukemia. Cancer Genet Cytogenet. 2008; 181(2): 125-30. https://doi.org/10.1016/j.cancergencyto.2007.11.010.

23. Nomdedeu $M$, Pereira A, Calvo $X$, et al. Clinical and biological significance of isolated $Y$ chromosome loss in myelodysplastic syndromes and chronic myelomonocytic leukemia. A report from the Spanish MDS Group. Leuk Res. 2017; 63: 85-9. https://doi.org/10.1016/j.leukres.2017.10.011.

24. Chen G, Zhou W, Gong D, Li Y, et al. Loss of X chromosome predicts favorable prognosis in female patients with $\mathrm{t}(8 ; 21)$ acute myeloid leukemia. Leuk Lymphoma. 2020; 61(5): 1168-77. https://doi.org/10.1080/10428194.2019.1709836.

25. Koukourakis MI, Giatromanolaki A, Simopoulos C, Polychronidis A, Sivridis E. Lactate dehydrogenase 5 (LDH5) relates to up-regulated hypoxia inducible factor pathway and metastasis in colorectal cancer. Clin Exp Metastasis. 2005; 22(1): 25-30. https://doi.org/10.1007/s10585-005-2343-7.

26. Banescu C, Tripon F, Trifa AP, Crauciuc AG, Moldovan VG, Boglis Aet al. Cytokine rs361525, rs1800750, rs1800629, rs1800896, rs1800872, rs1800795, rs1800470, and rs2430561 SNPs in relation with prognostic factors in acute myeloid leukemia. Cancer Med. 2019; 8(12): 5492-506. https://doi.org/10.1002/cam4.2424.

27. Piccirillo N, Laurenti L, Chiusolo P, et al. Reliability of leukostasis grading score to identify patients with highrisk hyperleukocytosis. Am J Hematol. 2009; 84(6): 381-2. https://doi.org/10.1002/ajh.21418.

28. Lazarevic V, Rosso A, Juliusson G, et al. Prognostic significance of high hyperdiploid and triploid/tetraploid adult acute myeloid leukemia. Am J Hematol. 2015; 90(9): 800-5. https://doi.org/10.1002/ajh.24091.

29. Luquet I, Lai JL, Barin C, et al. Hyperdiploid karyotypes in acute myeloid leukemia define a novel entity: A study of 38 patients from the Groupe Francophone de Cytogenetique Hematologique (GFCH). Leukemia. 2008; 22(1): 132-7. https://doi.org/10.1038/sj.leu.2404974.

30. Chilton L, Hills RK, Harrison CJ, Burnett AK, Grimwade D, Moorman AV. Hyperdiploidy with 49-65 chromosomes represents a heterogeneous cytogenetic subgroup of acute myeloid leukemia with differential outcome. Leukemia. 2014; 28(2): 321-8. doi: 10.1038/leu.2013.198. 
31. Sandahl JD, Kjeldsen E, Abrahamsson J, et al. Ploidy and clinical characteristics of childhood acute myeloid leukemia: A NOPHO-AML study. Genes Chromosomes Cancer. 2014; 53(8): 667-75.

https://doi.org/10.1002/gcc.22177.

32. Holmfeldt L, Wei L, Diaz-Flores E, et al. The genomic landscape of hypodiploid acute lymphoblastic leukemia. Nat Genet. 2013; 45(3): 242-52. https://doi.org/10.1038/ng.2532.

33. Pui $\mathrm{CH}$, Rebora P, Schrappe $\mathrm{M}$, et al. Outcome of children with hypodiploid acute lymphoblastic leukemia: A retrospective multinational study. J Clin Oncol. 2019; 37(10): 770-9. https://doi.org/10.1200/JC0.18.00822.

34. Peterson JF, Ketterling RP, Huang L, et al. A near-haploid clone harboring a BCR/ABL1 gene fusion in an adult patient with newly diagnosed B-lymphoblastic leukemia. Genes Chromosomes Cancer. 2019; 58(9): 665-8. https://doi.org/10.1002/gcc.22744

\section{Figures}




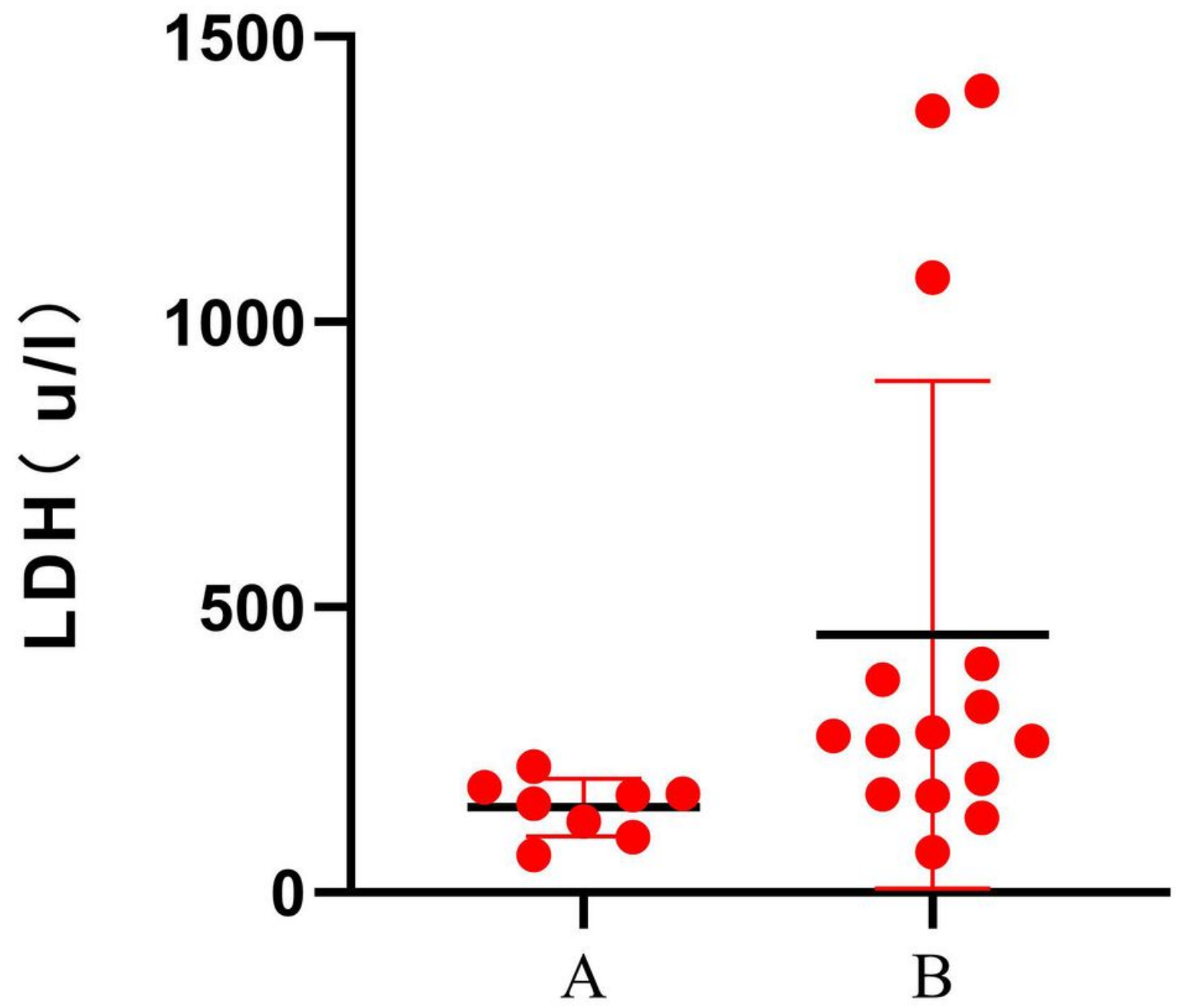

$A=$ Normal chromosome karyotypes $(n=8)$
$B=A$ bnormal chromosome karyotypes $(n=15)$

Figure 1

LDH level in normal and abnormal chromosome karyotypes. 


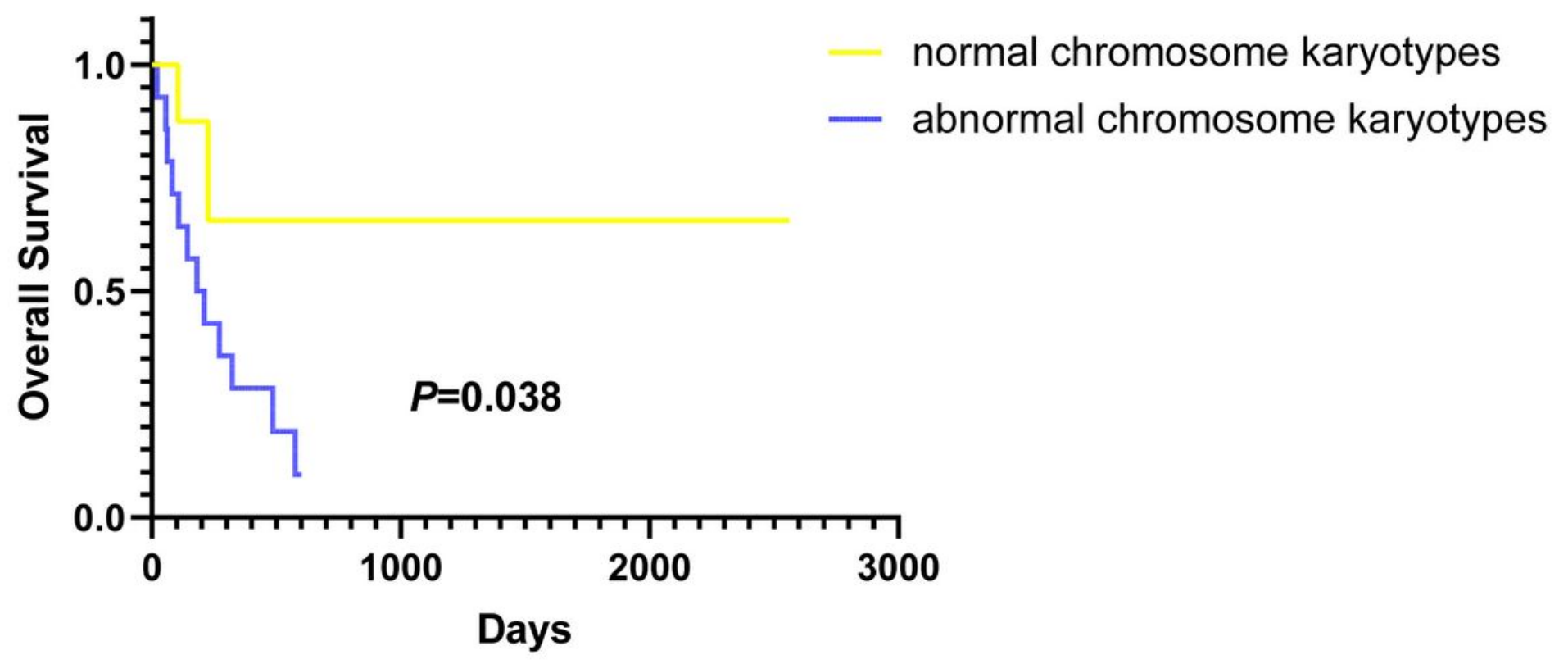

Figure 2

OS in normal and abnormal chromosome karyotypes of S-AML patients.

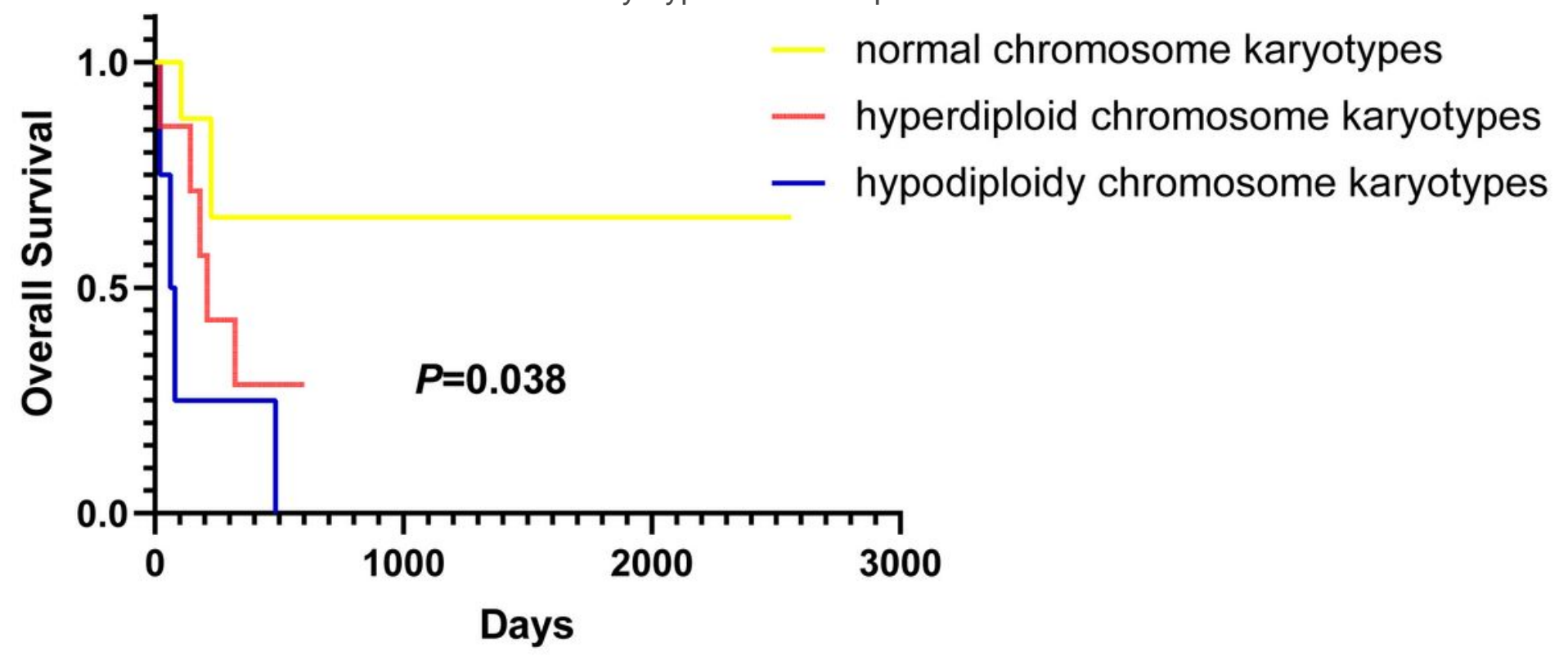

Figure 3

OS in normal, hyperdiploid and hypodiploidy chromosome karyotypes of S-AML patients. 